\title{
Assessing Elias on Marx in a neoliberal age
}

\author{
Steven LOYAL \\ School of Sociology, University College of Dublin, Irlanda \\ steven.loyal@ucd.ie
}

Recibido: $10-09-2012$

Aceptado: 19-12-2012

\begin{abstract}
This paper assesses Elias's recently published critique of Marx written in the 1960swithin the contemporary context of neo-liberalism. Based on a chapter written by Elias and intended for publication in What is Sociology? (1978) it argues that although Elias's makes some acute and penetrating points in his assessment of Marx, on occasion he caricatures Marx's arguments, and at other times recapitulates common erroneous criticisms. It argues that Elias's position is actually closer to Marx than his misjudged criticisms suggest, and that both writers, despite their differences, have a particular relevance in the current neo-liberalism context characterised simultaneously by increasing global interdependencies and a 'de-civilising' spurt.
\end{abstract}

Key words: Elias; Marx; neo-liberalism; economy; state

\section{Referencia normalizada}

Loyal, S. (2013). Assessing Elias on Marx in a neoliberal age. Política y Sociedad, Vol.50 Núm 2: 581-599

Sumario: Introduction. 1.Scattered remarks. 2. Karl Marx as sociologist and ideologist. 3.Assessment. 4.Conclusion. References

\section{Introduction}

In this paper I assess Norbert Elias's heretofore unpublished critique of Karl Marx. In doing so, it is not my task to provide a detailed evaluation of their theoretical convergences and divergences as expressed in their rich and diverse historical sociologies. This would require a substantial monograph. Nor do I aim to undertake a short exegesis in which Elias's original sociological oeuvre is reduced, or flattened to fit in with Marx's sociology. Rather it is to outline and assess Elias's insightful recently published chapter (contained in the English version of Collected Works) on Marx and Marxism within the context of a contemporary neo-liberal world characterized by a decivilising spurt. 


\section{Scattered remarks}

In Reflections on a Life (1994) Elias tells us that he spent a 'great deal of time reading Marx' early on in his career (1994:35). However, given his voluminous written output there are few systematic discussions about Marx. Instead we find several remarks and criticisms about Marx and Marxism scattered throughout his writings. ${ }^{1}$ Elias's criticisms centre principally around two criteria: Marx's exclusive focus on economic and class processes; and his curtailment of the role that consciousness plays in the constitution of social life. With reference to the former, he argues that class stratification as an explanatory determination, needs to be partly replaced by an increasing acknowledgement of the importance of nations and nationalism (Elias, 2008b), or that structured and sociologically explicable types of state oppression and forms of exploitation may be based on a non-economic basis (1971). In The Established and Outsiders, written with John Scotson, he reiteratesthe view that Marx's analysis of class and economic power is reductionist (Elias \& Scotson, 2008a [1990]: 211). For Elias, differences in the organisation of physical power, state formation, and the development of self-value relationships based on pride and social distinction also play a central part in different societies though according to different degrees. Hence, in addition to materialist explanations the operation of non-economic factors relating to the quest for status and recognition play a part in established -outsider relationships: 'the value one attaches to oneself as group or as individual person is ... one of the most fundamental ingredients of one's existence as a human being' (Elias \& Scotson, 2008a [1990]: 229). ${ }^{2}$ The need for status distinction has an important biological and historical

${ }^{1}$ Elias is not always critical and remains especially positive in reference to Marx's longterm theory of social development. These criticisms can be found inter alia in The Established and Outsiders (with J. Scotson), The Society of Individuals (1991(, as well as in various essays including those on the sociology of science (1971), and the socio-genesis of sociology (1984).

${ }^{2}$ For Elias struggles for the satisfaction of other human requirements may become more protracted when the certainty of material needs becomes established or where power balances are less uneven. He adds, 'Marx uncovered an important truth when he pointed to the uneven distribution of the means of production and thus to the uneven distribution of the means needed for satisfying people's material needs. But it was a half-truth. He presented as the root source of the goal clash between the power-superior and power inferior groups the clash over economic goals, such as that of securing a sufficient food supply. And to this day the pursuit of economic goals, elastic and ambiguous as this use of the term economic is, appears to many people as the real, basic goal of human groups, in comparison with which others appear to be less real, whatever that may mean' (Elias and Scotson, 2008a [1965]: 18). 
rationale for human survival. ${ }^{3}$ In Reflections on a Life (1994) he notes, that Marx reduces consciousness to social being, and that a 'dualistic thesis of conscious-less being and being-less consciousness is a fiction' (Elias, 1994: 34). These comments are not strikingly original, (and the second is a misreading of what Marx actually states), 4 yet that does not detract from the relevance of the first set of criticisms.

\section{Karl Marx as sociologist and ideologist}

Notwithstanding these scattered comments Elias's most systematic and explicit discussion of Marx is contained in a hitherto unpublished chapter entitled 'Karl Marx as a sociologist and a political ideologist' - a chapter that was originally intended to be published in his book What is Sociology? (1978), and has only very recently been made available. ${ }^{5}$ In the chapter Elias offers several original criticisms of Marx (and Marxists). Before outlining them it may be useful to contextualize their rationale within the overall context of the book. One of Elias's central concerns in What is Sociology? is to establish the basis for sociology as a science. It is to argue that the dynamics and long-term transformations of human figurations are the proper object of sociological investigation. Against the backdrop of the 1960s, where functionalism and Marxism had become dominant sociological schools of thought, Elias challenges the 'static' and 'unchanging', 'here and now' approach of Parsonian functionalism on the one hand ${ }^{6}$, and the political, ideological aspects of Marxism on the other.

3 'In the last resort these techniques may have a survival value. Collective selfglorification may strengthen the integration of a group, and thus improve survival chances' (Elias and Scotson, 2008a [1965]: 227).

${ }^{4}$ Marx's statement that it is not the conciousness of men that determines their social being but their social being that determines their conciousness is a critique of the Hegelian idea of a self-sufficient idealistic conciousness dialectically propelling itself forwards towards reason and absolute knowledge. For Marx, the concept of social being entails conciousness and in this context determines it in the sense of generating ideology. See Sayer, 1985]

${ }^{5}$ The chapter appeared for the first time in the German edition of Elias's Collected Works (2006) and is now forthcoming in the English version of the Collected Works (2012).

${ }^{6}$ Given that one 'can only understand what sociology is if one takes into account how it has become and is becoming, how the science is developing' (2012:176) it is important to examine the reasons for a 'shift in emphasis in the central interest of sociological research away from the attempt to clarify long-term social processes and to the attempt to clarify structures and functions of the various network phenomena, which are conceived more-orless, or at most as short-term, recurring processes within the framework of a society understood as unchanging' (2012:173-4).

${ }^{7} \mathrm{~A}$ third pole in this theoretical constellation - though not dealt with in detail in the book - is Karl Popper's philosophy of science. 
Eschewing both a philosophical absolutism in which 'one uses a system of ideas as an absolute standard [and applies them]...to the ideas of authors of earlier times under investigation' (2012:174) in order to praise and blame them, and equally a philosophical hermeneutical relativism in which 'ideas and observations are judged and evaluated exclusively in the context of their own society' (2012:175), he adopts what he calls a 'developmental approach'. Here 'a theoretical model is used as a standard for examining the dependence of many later areas of knowledge and modes of thought on earlier ones, and an attempt is made to determine the position and function held by the structure of ideas of a given author of an earlier generation within this sequence, in relation to knowledge and modes of thought which preceded it and followed it' (2012:175). Such an approach has demonstrable affinities with the scientific approach of the natural sciences in which there exists 'a comparatively high degree of continuity in research efforts over generations' (2012:177). ${ }^{8}$ It is within this framework of establishing a more scientific and less ideologically charged approach that he discusses several interconnected critical reflections about Marx and Marxism. These will be outlined below.

First, arguing against Marxists rather than Marx, Elias argues that although Marx was one of the first thinkers to provide intellectual tools for dealing with class differences - which Elias acknowledges is one of the central problems of industrial societies -sociologists have tended argue for or against Marx as if he were 'a contemporary living in the $20^{\text {th }}$ century', and as if his concept of class was equally valid for earlier and later times. The concept of class has therefore been effectively frozen and 'reduced to a state' by sociologists for political reasons: 'What purpose could it serve if sociologists - say in the years 1850, 1880, 1910, 1940, and 1970 sought to clarify the concept of class by interpreting theoretical models of class relationships on the basis of the class stratification of industrial countries they happened to find present in their own generations, as if that were the concept of class per se, valid for all earlier and later times? They would act as if the aim were to determine what emerges as the eternally unchanging characteristics of classes if one completely ignores the fact that industrial societies - the very thing to which the concept of class relates - have changed since 1850 in a very specific way which

\footnotetext{
${ }^{8}$ In sociology 'continuity in the understanding of certain sociological areas and in the development of theoretical models is, comparatively, still very slight. Indeed one of the most urgent tasks of sociology is to strive for greater continuity in research on both the empirical and theoretical level.' For Elias the fluctuations of sociological interest are still great' and sociology 'as a science of society ... is dependent to an especially high degree on the development of the society to which particular sociologists belong. The way in which it selects and poses problems, and often enough the solutions proposed, are still far more directly determined by the comings and going of problems in the whole society than in the case of the physical and even the biological natural sciences'(2012:177-8). An example of this is the academic preoccupation with sociological problems highlighted by Marx, especially those concerning class relations.
} 
is accessible to precise structural analysis' (2012:178-9). According to Elias the Marxist theory of class should instead be viewed as 'a theoretical analysis of class relationships in industrial societies at a particular stage of development' (2012:184). Having championed the more scientific and detached nature of the natural sciences, Elias nevertheless warns against a reduction of the social sciences to them: the subject matter of sociology changes at a higher tempo than that of the natural sciences. Rather than imagining that one is investigating unchanging and static processes and seeking 'eternal laws' it would be more appropriate if the development of class structures and relationships in industrial societies, especially in light of the more comprehensive knowledge we now have about these processes, was included as an integral component in any theory of social stratification. Marx made a start in this direction by presenting both class relations and the relations of production as processes undergoing development but, for political reasons, gave a teleological twist to this argument by conceptualising the working class in absolute terms - as an eternal unchanging working class that would exist until all classes disappeared. Like many other social thinkers, "Marx the sociologist saw [the] developmental character of class structures clearly enough, even though, as a political ideologist, he constantly covered up what he perceived as a scientist' (2012:180).

Second, Marx wrote during the early industrial period in England, a time in which there existed a protracted contrast between the living condition of the workers and those of the upper strata of society. Elias quotes James Philips Kay, a doctor writing during the nineteenth century, to convey the gruelling social conditions of the working classes living during early industrialisation in England. The poverty, pestilence, sickness and epidemics affecting the poor are markedly counterposed by Kay to the living conditions of the upper strata of society. It is this stark existential class cleavage that was reflected in Marx's theory of class relations as a theory of power: '[Marx's] ideas undoubtedly corresponded to the brutality of the socially stronger in relation to the socially weaker class, which he himself, and certainly not only he, was able to observe in his society' (2011:184). This context enabled Marx to become one of the first sociologists to confront a fundamental problems in sociology, the role of power, and to conceive it not as a 'structureless possession of individual people, but as social opportunities which accrue to certain groups of people as a result of their changing social positions' (2012:185). For Marx recognised that groups who have greater power opportunities exploit this superiority optimally until they are disempowered by a shift in balance in power.

9 'Men so different in their ideals and in their concepts of social development as Comte, Spencer, Marx and Hobhouse, to name only a few, had this in common: each had a firm vision of the future of mankind which represented at the same time what he wished society to be, what he morally field society ought to be and what he prophetically believed society would in fact be. (2012:185) 
The core of Marx's theory of class relationships is the argument that 'the entrepreneurial class uses to the fullest extent, without any restriction by humanitarian or religious scruples, the greater power potentials it derives in the course of social development from the monopolisation of the ownership of capital in relation to the working class.' However, as before, Marx's profound scientific insight was 'thwarted by his temperament and his emotional commitment' (2012:185).

Third, Marx wrote in a context where a brutal free play of forces held sway, so that the use of physical violence based on numerical superiority was 'the only possible solution to the class antithesis' (2012:184). Consequently, although Marx acknowledged the role of physical force in social life, he was unable extend this insight to a more exact exploration of the monopolisation of physical force as one of the social sources of power potential of various groups. The Marxist view that power structures were governed solely by the exploitation of existing power differentials and unregulated by any norms that could be agreed and recognised by both sides, in some ways represented a dialectical counterblow to the laissez-faire theories of Smith, Ricardo, and specially Malthus. Marx's view of power differentials, though an important counterweight to a functionalist theory preoccupied with integrating norms, represents an equally one-sided account since it ignores the crucial role that norms play in controlling and regulating human behaviour. Following a long series of power struggles, both Marx and subsequent Marxists failed to envisage the development of integrating norms that were binding on both sides of the conflict, and which had the effect of regulating previously anomic regions of social life and bringing them under human control. For Elias these mutually accepted norms and controls have alleviated the harsher aspects of the power struggles that Marx witnessed. Institutionalized struggles between industrial firms as well as individual workers in fixed associations, such as trade unions, both regulated by laws have now (Elias was writing in the 1960s) become the norm. Tacitly referring to the Cold War context, he argues that although interstate interdependencies are still insufficiently regulated by norms and characterised by incessant trials of strength because of stark power differences, these conflicts are less pronounced in the case of intra-state relations.

Fourth, in assessing the Marxist model of the development of European societies Elias acknowledges the seminal importance of Marx in pioneering an examination of long-term structural changes in society entailing social power struggles. However, Marx's interpretation of these changes is overly simplistic and should not be treated as an authoritative and definitive account. Marx analyses two phases: In the first, following the development of European societies and a growth in the relations of production and technology, Marx depicts a struggle between feudal and rising bourgeois groups. In the second, he outlines an endemic conflict between the bourgeoisie and the proletariat - in which the latter become victorious. For Elias, the use of the term 'feudal' to refer to noble and privileged groups supported primarily by land ownership masks the fundamental social, political and economic changes that this group underwent over the course of centuries. Specifically it 
glosses over the changes between knightly noble groups living predominantly on income paid in kind in the loosely centralised states of the Early Middle Ages between the $11^{\text {th }}$ and $12^{\text {th }}$ centuries and the court aristocratic ruling elites of the $17^{\text {th }}$ and $18^{\text {th }}$ centuries who primarily resided at the great courts and depended upon money income. For Elias court traditions and court logic were fundamental forces pacifying society, shaping state power, and defining the behavioural parameters and habitus of modern society. These processes are simply overlooked in the rigid feudal/capitalist dichotomy that is adumbrated by historical materialism.

Fifth, although Marx recognised the shifting power opportunities that rising strata acquired and the correlative defunctionalisation and disempowerment characterizing other social groups without reducing these processes to the level of individual explanation, he nevertheless problematically saw the development of classes as taking place in a unilinear direction in all industrializing countries. Industrialization -(Elias uses the term with hesitation)- played a decisive role in the development of all European countries, however, an explosive outburst of violence by rising bourgeois groups against declining aristocratic dynastic groups only took place in France. In Germany the ensuing violence took place in conjunction with lost wars, while in England, such processes unfolded peacefully gradually over centuries, and partly through parliamentary struggles. Marx's singular emphasis on spontaneous and abrupt violence has hindered a more realistic understanding of historical events in which revolutions were not the cause of the fall of the aristocracy but, rather, the effect of a prior shift in power that had disempowered previously privileged elites. By comparing the French, Russian, and Chinese Revolutions we can see that the traditional rigidified institutional structures and distributions of power in all three cases meant that the dynastic-aristocratic monopoly elite class could not adapt to the power changes underway and could only be removed through violent means. ${ }^{10}$ Viewed scientifically- and here Elias seems to follow Weber- it is not possible to justify the view that the overthrow of the bourgeoisie is inevitable, only that it may be possible. But even here we need to look at why large-scale revolutionary processes have taken place primarily in

${ }^{10}$ As he notes: 'In the history of all pre-industrial dynastic-aristocratic state societies, we find numerous uprising aimed at disempowering the present holders of power, whether princes or their ministers. But as long as the re-structuring of such societies in the form of advancing commercialisation and industrialisation, with the concomitant urbanisation, has not yet started, or has not yet progressed far enough, even uprisings do not bring about a restructuring of society and the access of new strata as such to the central monopolies of the state. They lead, at most, to the replacement of the old dynasty by a new dynasty. The incumbents change, but the regime does not. The reason why a revolution is a revolt which results in a change in the structure of the regime itself is that, in this case, the rebelling groups act as executors of a social shift of power which was already in progress before the revolt began.' He adds, 'Factors of international politics, defeat in war, failure to keep pace with other countries, also favour the onset of revolutionary processes.' (2012:193). 
preindustrial or more agricultural societies and have largely remained absent from more industrialised societies.

Sixth, Marx's view of society was limited by the conceptual apparatus and stock of knowledge available to him during his life time. Marx treated the economy as if were in conceptually and substantive isolation from other spheres in society, especially the state. This reflected his immediate social and intellectual context wherein the economic sphere 'possessed a high degree of autonomy in relation to other spheres of society' and laissez-faire economics was a dominant intellectual current. The latter aimed to demonstrate the operation of quasi- natural autonomous market mechanisms when states refrained from intervening in economic and political life but in fact expressed the interests of the middle-classes and their commanding positions in the state monopoly institutions. For Elias the argument that a conceptually isolated economy should be given primacy over the state, as Marx had argued, or vice versa (the ultimate position of laissez-faire economists and the business strata) constituted a false problem. In terms that echo the work of Polyani (1944), Elias notes: 'Even though the science of economics may concern itself specifically with economic mechanisms, from a sociological point of view the aspects of the social interconnections dealt with by the economic sciences are conceivable only within the framework of societies organised as states. The groups of positions in a society which specialize in economic activity, and those which integrate the state form, with one another, a unified functional nexus' (2012: 197).

Seventh, and lastly, Elias considers that the greatest weakness in the Marxist conception of society was Marx's failure to see the long-term shift in the balance of power towards the subordinate classes: 'It can be observed that the development of society in the last two or three centuries has moved in a direction which makes it increasingly difficult for more powerful strata to take unrestricted advantage of the superiority of their power opportunities. In fact, one sees a pronounced trend towards a distribution of power between previously more powerful and previously less powerful groups which - although certainly not equal - is at any rate less unequal' (2012:194). Processes of functional democratisation have significantly redistributed power chances from more powerful middle class employers towards less powerful working class groups. However, such a shift has been masked by an exclusive focus on the capital-wage relation. There is a need, for example, to compare the relative power of workers associations in the 1860s to the 1960s, in terms of the latter's ability to influence the government. Seen in the long term perspective formerly excluded middle class groups have gained increasing access into the central power positions of the state formerly held exclusively by princes and aristocrats. This has been followed, albeit to a lesser extent, by the working classes entering the realm of power. The accruing of greater power opportunities to wider and wider strata has followed industrialisation.

Elias concludes by arguing thatMarx's de-historicised conception of class needs to be urgently replaced. In its place Elias offers his own unique definition. Here the concept of classes, 'refers to interdependent groups of social positions within a state which are interconnected functionally in such a way that the incumbents of 
position-group A are normally more dependent on the incumbents of position-group B than vice versa, and that normally the advantages that accrue to the latter group from this balance of power and interdependence are credited to them in the form of income, status, education and all kinds of opportunities of control' (2012:197).

Elias ends his chapter by restating its central overaching premise. Although Marx was a great pioneer in sociology, the ideological aspects of his workprimarily the utopian desire to see a socialist society emerge- prevented his work from becoming truly scientific: 'All this points very clearly, on the one hand, to the greatness of Marx's sociological achievement. He brought together theoretically a whole range of key problems of social development, and thereby made them accessible to further scientific work. It points, on the other hand, to the unavoidable limitation that the time bound material of his experience imposed on his theoretical construction, and the damage inflicted on the Marxian thought-edifice by the fact that its function as the Bible of a great political movement constantly obscures its function as a pioneering work of sociology' (2012:197).

\section{Assessment}

How should we assess Elias's extensive critical reflections on Marxtaking into account that many of his criticisms centre on the contradiction between Marxism as a science and Marxism as a political ideology? Given limitations of space I will not be able to address all of Elias's criticisms. Moreover, reaching a balanced assessment of Elias's criticisms is not a straightforward enterprise which raise a numbers of questions. Firstly, how are these criticisms to be seen in terms of his other critical comments concerning Marx outlined at the beginning of this essay? Second, Elias appears to be inveighing more against Marxists and neo-Marxists, (including Western Marxists such as Marcuse, Adorno, and Sartre whose ideas held a dominant position in the sociological field during the 60s) rather than to Marx himself. Third, Elias does not read Marx according to his own historical context but, rather according to a developmental approach outlined above and in terms unfolding problems that have confronted sociology since its inception. This means that Elias is not attempting to provide a comprehensive but selective evaluation of Marxism. More specifically, he interprets Marx according to long-term processes of sociological analysis, and shifting dynamic power relationships as expressed through established-outsider relations. Such a symptomatic reading has both merits and drawbacks. What are considered by many as Marx's more profound or enduring sociological insights are simply left un-discussed. These include his theory of alienation (Meszaros, 1970), the contradiction within the commodity form (Rosdolsky, 1989), concrete and abstract labour power (Sohn-Rethle, 1977), dialectics as a method (Lukacs, 1971), the contradiction between the forces and relations of production (Plekanov, 1940), the formation of private property (Godelier, 1986), Marx's analysis of commodity fetishism and of capital as a social relation (that takes on an appearance of a relation between things) (Lukacs, 1971; 
Adorno and Horkheimer, 2002[1944]), the dynamic nature of capitalism (Harvey, 1970; Berman, 1982) and capitalism's intrinsic and unrelenting search for profits (Sweezy, 1948; Brenner, 2002). Yet, on the other hand Elias's interpretive procedure allows us to focus in more detail on core historical themes in Marx's work.

Perhaps in response to Elias, and paradoxically, it could be argued what makes Marx's work so sociologically powerful is his involved political affiliation to the working class ${ }^{11}$-precisely the factor that Elias identifies as a scientific hindrance. Adopting the concrete standpoint of labour (as opposed to the standpoint of capital which reflected previous forms of political economy), allowed Marx to understand and delineate emerging conflicts and contradictions within capitalist society within a powerful social theory. More recently it has often been the absence of such an explicit alliance between theory and working class practice that has resulted in the shortcomings and deficiencies characterising not only a number of neo-Marxist writers, the so called Western Marxists (Anderson, 1977) but other sociological theories written at high levels of abstraction containing convoluted jargon and lacking an empirical frame of reference (Wright-Mills, 1973[1959]). That this conjunction of theory and practice sometimes led Marx to confuse scientific analysis with ideological wish-fulfilment is unmistakable. For example Marx often saw the beginnings of a large-scale socialist revolution in small historical class insurgencies or minor political events. Given Marx's expansive oeuvre, it would be unusual for contradictions, opacities and inconsistencies not to be present in his work. However, this is undoubtedly exacerbated by the explicitly political nature of Marx's work construed as a political practice. Marx was not an academic sociologist but a revolutionary who saw his work as simultaneously scientific. Writings such as the Communist Manifesto (1848) aimed directly at mobilising a rising revolutionary class movement, or more informal and polemical journalistic pieces often contained arguments that rested at odds with relatively more detached scientific works, such as Capital (1990[1967]). Elias, with the exception of a letter to Weydemeyer that he cites, focuses almost exclusively on Marx and Engel's Communist Manifesto. Consequently his comments create a caricature of Marx against which Elias then establishes his own position, which is in reality, not so distant from Marx's own. Below I will discuss the relevance of these criticisms in the order in which Elias makes them, save for the third criticism, which I will deal withat the end.

In his first and second criticisms of Marx, Elias discusses the de-historicized application by contemporary Marxists of Marx's $19^{\text {th }}$ analysis of class to modern societies. Here he draws on arguments made by Dahrendorf (1959) concerning the

${ }^{11}$ Marx's formal ties with working classes organisations began first with the League of the Just for example and then later from mid 1860s with The Working Men's International association (also known as the First International). 
altered socio-economic characteristics of modern social formations as compared to Victorian industrial societies in which Marx was writing. The point Elias makes has some validity when applied to Marxists and neo-Marxist: there has been a definite pronounced tendency for these thinkers to apply static dichotomous models of class on to complex, amorphous and fluid class configurations. ${ }^{12}$ However, Marx’s own practice of applying the concept of class is less clear. Despite the centrality of the concept in his work, Marx never provided an explicit and systematic definition of the concept, and there is voluminous and ongoing debate about its 'conceptual slippage' in his work (Thompson, 1978; Wright, 1985). The simple binary view contained in the The Communist Manifesto (1848) is complicated by more complex and nuanced account of class fractions in The Eighteenth Brumaire (1973[1858]) and diverse and sometimes inconsistent formulations in Theories of Surplus Value (1863) and Capital Volume III (1865). ${ }^{13}$ This conceptual fluidity, as Sayer (1987) rightly points out, reflects both the relational and the historical character of social reality itself and the various different levels of abstraction at which Marx, like Elias, applies his categories. Marx's dialectical method uses both a relational and procesual conception of class (Ollman, 1991; Sayer, 1987). Such empirical and historical complexity notwithstanding, there is a consistent kernel in Marx's interpretation of class which Elias does not mention. This emerges from his vision of an overarching trajectory in historical development, and the commitment to social relations of material production as the key analytic point of departure. Although class as a general category applies to all previous agrarian societies, Marx insisted on the specificity of class relations under capitalism. In pre-capitalist societies, the processes of exploitation and surplus production were based upon a multiplicity of 'extra-economic' factors (and notably including legally sanctioned

${ }^{12}$ Equally, contemporary quantitative approaches to class, often assume, for example (though they use a different conceptual idiom), that when a bourgeois groups rises, other groups such as the nobility will simultaneously fall, or that when the proletariat rises, the bourgeoisie will decline. Like Wittgenstein, Elias recognises that language often misleads us by obscuring both difference and dynamic processes. Thus not only does the content of our class concepts change historically, but also the same class designation often covers social formations of different types or, in other words, different stages of an overall social development (Loyal, 2003).

${ }^{13}$ The Communist Manifesto has a dichotomous view of class in which two great classes - bourgeoisie and proletariat - face each other and propel society forward through social and political struggle. But other work recognises numerous gradations of strata. There are discussions of the middle classes in the Theories of Surplus Value, as well as of 'the three great classes of modern society' including wage-labourers, capitalists and landlords with 'an infinite fragmentation of interest and rank' in volume 3 of Capital. In The Eighteenth Brumaire of Louis Bonaparte Marx outlines various class fractions including the landed aristocracy, financiers, the industrial bourgeoisie, the middle class, the petty bourgeoisie the industrial- and lumpen - proletariat, and the peasantry. 
violence), which characterized a situation of 'personalised dependence'. Under capitalism, processes of economic exploitation for the first time come to operate purely in relation to objective and abstract economic criteria. With the severing of property from its 'former social and political embellishments and associations' (Marx, 1865: 618), the subordination of the labourer becomes guaranteed by the ‘dull compulsion of economic relations’ (Marx, 1990[1867]: 737).

In some ways Elias's model has affinities with Marx's, rather than the neoMarxist approaches he criticizes. His historical sociology also posits a processual model of class which recognises the importance of long-term structural changes and transformations in class structure. It is only in this context, across the sweep of centuries, that one can see that the sharp contrasts between the behaviour of different social groups steadily diminishing. Here, classes are made and remade in specific conjunctures of figurational complexes where balances of power remain tensile and fluid. This perspective brings into view the permanent interdependence of rising and sinking movements, and processes of class integration and disintegration. It also shares a good deal of conceptual symmetry with E.P. Thompson's work on class as a process: 'By class I understand a historical phenomenon, unifying a number of disparate and seemingly unconnected events... I emphasise that it is a historical phenomenon. I do not see class as a "structure", nor even as a "category", but as something which in fact happens" (1968:9). ${ }^{14}$ Thompson's dialectical approach also rejects both unsophisticated forms of conceptualisation and crude impositions of a base/superstructure model operating on the basis of an ideal/material dichotomy.

In his fourth criticism, Elias is of course right to point to the failure of Marx to look at court society as a transitional phase between capitalism and feudalism. This omission ultimately follows from Marx's ontology with its singular focus on productive activity, property relations and ownership, at the expense of state and social relations. From a Marxist viewpoint Absolutism, though significant in terms

14 Thompson states: 'When, in discussing class, one finds oneself too frequently commencing sentences with "it", it is time to place oneself under some historical control, or one is in danger of becoming the slave of one's own categories. Sociologists who have stopped the time machine and, with a good deal of conceptual huffing and puffing, have gone down the engine room to look, tell us that nowhere at all have they been able to locate and classify a class. They can only find a multitude of people with different occupations, incomes, status-hierarchies, and the rest. Of course they are right, since class is not this or that part of the machine, but the way the machine works once it is set in motion-not this interest and that interest, but the friction of interests-the movement itself, the heat, the thundering noise... When we speak of class we are thinking of a very loosely defined body of people who share the same categories of interests, social experiences, traditions and value-system, who have a disposition to behave as a class, to define themselves in their actions and in their consciousness in relation to other groups of people in class ways. But class itself is not a thing, it is an happening' (1978: 295). 
of governance, did not fundamentally alter the overall pattern of property relations and surplus extraction processes that unfolded during the late Middle Ages. This is of course a contentious point. Elias's more detailed analysis allows for broader and more intricate behavioural patterns in human societies to be discerned, this includes pacification and the emergence of a bourgeois 'accounting' ethic alongside an aristocratic ethic of conspicuous consumption (Elias, 1983). However, his work can also possibly be read in some ways as an extension of Marx's arguments rather than a wholesale refutation of them.

Elias's insights in his fifth criticism concerning revolution are equally insightful especially given the recent Arabic revolutions in Tunisia, Egypt, Libya and Syria. These revolutions have demonstrated not only the importance of shifts in the balance of power between social groups, but also the critical role that the indigenous military and international support from the West played in the revolutions. Elias is surely right in criticizing Marx for not having a systematic or fully developed discussion of revolution given its prominence in his work. However, ${ }^{15}$ his argument that Marx saw revolution as the only means of uskering in a transition to socialism, and as a spontaneous event, is less convincing. In fact both Marx and Engels, especially in their later writings, envisaged the possibility of a peaceful transition from capitalism to socialism if certain social conditions existed. (Schaff, 1973: 265). In his speech to the Hague Congress of the International, on September 15, 1872 Marx stated: 'one day the workers must take over the political power in order to build a new organization of labor; they must destroy the old political system which strives to preserve the old institutions, if they are not to be deprived of the heavenly kingdom on the Earth, as it occurred to early Christians who neglected to do the same. But it cannot be claimed that the paths to that goal are the same everywhere. It is necessary to take into consideration the institutions, manners, and traditions in the various countries. It cannot be denied that there are countries, such as America, England, and perhaps the Netherlands, in which the workers can attain their goals peacefully' (cited in Schaff, 1973:266-7). ${ }^{16}$ They believed that England, Holland and the USA could move peacefully towards a socialist society (Eagleton, 2011: 192). ${ }^{17}$ Marx did not have one catch all theory of revolution but recognised that different societies had different social conditions

${ }^{15}$ Marx was concerned, it should be added, not just with political revolution but with a social revolution.

${ }^{16}$ In his Preface to the English-language version of Capital Engels wrote in 1886 that Marx was "... led to the conclusion that, at least in Europe, England is the only country where the inevitable social revolution might be effected entirely by peaceful and legal means. He certainly never forgot to add that he hardly expected the English ruling classes to submit, without a 'pro-slavery' rebellion, to this peaceful and legal revolution."(1990:[1867]:113)

${ }^{17}$ In the USA for example a this was because a strong state bureaucracy and developed military capacity was absent. 
which had to be recognised. Elias's comments concerning the replacement of one elite grouping by another, without a significant shift of power taking place, in fact has close parallels with Marx's discussions in the Eighteenth Brumaire of Louis Napolean (1973[1858]). Moreover, pace Elias, Marx’s views on revolution were not shaped wholly by the French Revolution, but rather by the 1848 revolutions which swept through Europe in France, Germany, Austria, and Czechoslovakia, and later by the Paris Commune in 1871.

A further aspect of Marx's view on revolution has significant parallels with Elias. Marx did not see revolution as an abrupt and spontaneous phenomena, but rather, as resulting from prior shifts in power relations following class struggle. Revolutions therefore followed long-term shifts in power which itself was the result of internecine class struggles; they were not spontaneous events, as anarchists imagined, but depended upon working class organisation and politicisation.

Elias's sixth criticism concerns Marx's conceptual separation of the state and economy and the ultimate explanatory role accorded to the latter at the expense of the former. Marx as is well known, never provided a systematic discussion of the state, though a volume explicitly looking at its role was intended in his original plans for Capital. Elias is right to point to both the stark separation of state and economy in Marx's writings and Marx's predominantly economic conception of the state's role. ${ }^{19}$ Yet in other work, for example the Eighteenth Brumaire (1973 [1858]), the state is afforded a relative autonomy from class configurations, especially in relation to military power: 'The struggle seems to have reached the compromise that all classes fall on their knees, equally mute and equally impotent, before the rifle butt' (1973 [1858]:236). The state is 'an immense bureaucratic and military organisation, an ingenious and broadly based state machinery, and an army of half a million officials alongside the actual army, which number a further half million' (1973[1858]: 237). Effectively the state becomes, as Milliband argues, 'an institution in its own right, with its own interests and purposes' (Milliband, 1991:521). Nevertheless, despite these insights, Marx generally downplayed the role of the state and treated it at too high a level of abstraction. As Elias points out, this may possibly have been a result of its more 'minimal role' during Marx's own

${ }^{18}$ At no other point during the $19^{\text {th }}$ century as Calvert has claimed 'were there so many revolutionary movements available for examination and study. It has been estimated that in the small states of Europe in 1848-9 there were no less than 50' (Calvert, 1970:84).

${ }^{19}$ In his various writings he generally discussed the economic functions of the state as a relation of production, distinguishing between its ideological appearance as serving the general interests of society as a whole, and its essential relations that function to promote the specific interests and needs of the bourgeoisie in the accumulation and reproduction of capital (Sayer, 1985). He also saw its repressive aspects geared towards the maintenance of social order and private property and exploitation as central functions. In Capital Marx he is even more explicit about its economic role, predominantly focusing on the state's role in the regulation of the monetary order. 
time. State spending in relation to the economy is estimated to be around $10 \%$ in Marx's day whereas it is now over 35\% (Allen, 2011).

I will discuss the third and seventh criticism that Elias makes together, since they significally overlap. In his third criticism Elias argues that Marx was unaware of social reform and instead preoccupied by a revolution taking place in the context of Victorian capitalist society, where a 'free reign of forces existed'. However, Marx was fullyconversant with, and in fact sympathetic to, various reformist institutions including trade union movements, political newspapers, struggles over universal suffrage, and the shortening of the working day. However, he felt that reformist changes introduced would ultimately be limited and thwarted by the more powerful logic and needs of capital and state. He therefore failed to see the longterm impact of their institutionalisation. But this wasn't the only thing he failed to predict. Perhaps equally as significantly was his failure to see the growth of social democracy, the growth of imperialism, a powerful corporate media, and the welfare state, and as Elias has pointed out elsewhere, the role of nationalism.

Elias's argument that Marx's failed to envisage both the long-term shift in the balance of power towards subordinate classes from the superordinate classes,or the development of integrative norms, needs to be qualified. The European working class has undoubtedly moved away from the stark existential poverty endured and some of its members if we take class have entered into positions of governmental power. However, absolute differences in the concentration of wealth, for example, these have now been replaced by stark relative differences. If we take the US as an illustration, the top $1 \%$ of households hold $35 \%$ of all privately owned wealth, so that the gap between rich and poor is at its highest level since 1917 (Allen 2011:55). Equally, Marx's failure to see the development of integrating mutually accepted norms and controls that have alleviated the harsher aspects of the power and class struggles, needs to be qualified. In judging Marx in terms of the development of integrative norms, Elias was writing during the late 60s and 70s where a European corporatist Fordist-Keynsian compact between employers, unions and the state existed. However, an ideological and material shift from the state's social functions as guardian of the public interest with responsibility for social housing, universal and affordable health care, public transport and social inclusion and equality has taken place over the past 30 years under the pressure of neo-liberalism (Harvey, 2001). Keynsianism has given way to the pursuit of private interests, private enterprise, deregulation, and fiscal and budgetary cuts. Expressed ideologically through a neo-liberal trope of no rights without responsibilities, and an exaggerated stress on economic and social individualism, this can in some ways be seen as a decivilising spurt which includes the remaking and reshaping of the state itself (Wacquant, 2003). Such a shift means that the treatment of workers has deteriorated significantly and integrating norms have become part of an intense hegemonic struggle. It could be argued that the conditions of migrant workers in parts of the 
world, for example, are in some ways analogous to the thick descriptions of worker exploitation and working conditions Marx famously outlined in Capital (Marx, (1990[1867] pp340-416). ${ }^{20}$ It is important to see this process in a long-term perspective and it remains an empirical question how the balance of class forces will shift again in the coming decades. Whether there will be a move towards functional democratization or, within the context of growing global politicaleconomic inequality, is unclear. Elias of course would probably have had no problem in accepting the emergence of such processes within his sociological framework. As he notes: 'How far and why the balance of power between the two classes has shifted since Marx's time in favour of one side or the other is a question which can only be answered in more precise empirical investigations (2012:197).

Nevertheless, there is also a sense that both Marx and Elias, though acknowledging global processes in their theoretical frameworks, for the most part focused their sociological attention too narrowly on European affairs and failed to discuss the sharp power balances characterising a number of countries in the rest of the world, especially in the South of the globe. The shift in manufacturing production, from North to South and concomitant processes involving primitive

${ }^{20}$ In Marx's time all that existed in UK, as he discusses in detail Capital (1990 [1867]), were the Factory Acts but they, within the context of laissez-faire world, were interpreted loosely and rarely enforced.

${ }^{21}$ Elias himself has written about such free market economic philosophies (Elias, 1984). It was not the idea of "laws", of self-regulating forces in society as such which constituted an innovation of thought. That idea had been the key-note of many philosophi' cal doctrines before. It usually took the form of a belief in nature as the regulative force in society. Left to i.ts own devices undisturbed by the artificial interference of unenlightened governments, that was the gist of the argument, nature in society would on its own produce a happier and more harmonious life among men. Rousseau's work was only a paradigmatic crystalisation of a strand of feeling in that sense which run through many writings and discussions of 18th century society. But like many other philosophical ideas of that age it had the form of a social creed. One believed it or did not believe it, but one did not think of it as a scientific doctrine in need of empirical verification. (1984:20). The Physiocrats as well as Adam Smith were profoundly influenced by this social creed. Both believed that nature in society if only its own "laws" were allowed to assert themselves freely, would automatically secure the welfare and prosperity of men. But in their case the social belief in the goodness of nature as a self-regulating force in society was brought into closer contact than before with a body of empirical evidence. The Physiocrats first, and a little later Adam Smith and others, used empirical data to demonstrate the "laws", the self-regulating forces operating in society...The demand for free competition as a simple practical measure had been made long before "free competition" became the centrepiece of an "economic" theory. Mercantilist writers had collected and, on a small scale, conceptually organised a good deal of the knowledge about self-regulating mechanisms which we now classify as "economic".The intellectual innovations of the Physiocrats, like those of Adam Smith, were to a large extent feats of synthesis. (1984:21). This was all bound up with the emergence of the term 'economic' 
accumulation as Mike Davis (2007) has shown, has meant that nearly half of the world's population live now in slums.

\section{Conclusion}

Elias wrote his unpublished chapter on Marx in the mid to late 1960s, at a time when Marxist sociology, together with Parsonian functionalism had become dominant intellectual sociological worldviews. Written during a social context characterized by workers militancy, student revolts, support for cultural Maoism, and a Cold war context heteronomous political values became enshrined and taken for granted within a ossified and dogmatic Marxist sociology. However, the collapse of the Soviet Union and the rise of an equally politically driven critical postmodernist sociology have had the unintended effect of making Marxist sociology both less reductionist, and more scientifically balanced and analytically stronger. But they have also engendered a new socio-political context characterized by neo-liberalism and an era marked by a relatively increasing international geopolitical interdependency. It is in this fundamentally altered context that I have undertaken an evaluation of Elias's criticism of Marx. The article has argued that some of Elias's criticisms of Marx were certainly justified, but a number were also misjudged and effectively painted a caricature of Marx's writing. It was further argued that Elias and Marx in fact share a number of elective affinities in their historical sociologies. Some of these can be accounted for in the fact that both transcend a number of Enlightenment and post-Enlightenment dualisms: while emphasizing the inherently social nature of humans both recognized at the same time their modern individuation; both see the continuity and discontinuity between understanding nature and understanding human behaviour; both acknowledge the importance of theory, yet express it through empirical discussions; both admire the work of Darwin as a model of science yet see the social world as having its own peculiar logic. More importantly, both thinkers focus on dynamic social relations not just in terms of lip service but, by actually taking the concept to its logical conclusions. ${ }^{22}$ This is of course not to downplay their differences which arise from the different historical periods in which they were writing, the fundamentally different social questions they engaged, and their intellectual sensibilities - the pursuit of relative academic detachment on the one hand, and impassioned revolutionary engagement on the other. Nor does it mean overbooking their different political positions - radical social democrat versus revolutionary socialist,

${ }^{22}$ As Mennell notes: "Elias, like Marx himself, is always looking for the immanent dynamic of real social relations between people - relations including unequal, exploitative interdependence, and the internal tensions which cause change - and why development went one way rather than another' (Mennell, 1992: 66). 
or denying their different sociological contributions and the explanatory constellation of concepts they introduced: figurations, interdependencies, game models, processual analysis, and the unintended consequences of actions, on the one hand; and modes, forces, and relations of production, capitalist crises, the unyielding search for profit the endemic conflict between capital and labour, and the reification and alienation of social relations, on the other.

Nevertheless, the importance attributed to the profoundly social nature of humans, an emphasis on long-term historical processes, and the dynamics of power relations make their sociological visions partly compatible and complementary in many ways especially in the modern conjuncture. We can therefore understand Elias's desire to move beyond Marx in two ways. Beyond as in ignoring and bypassing Marxism as an outdated and irrelevant sociology, or beyond in a second sense, as in expanding and developing Marxism as a form of thought while recognising its inherent limitations and expanding on its insights. I think Elias should be read in the latter sense. Writing almost 50 years after Marx he is able to move beyond the limited social horizons which circumscribed Marx' thought. As he himself states in the Established and Outsiders, the 'great discovery' in Marx's work is not to be read as the 'end of the road to discovery about human societies [but]...as one manifestation of a beginning' (2008:18).

\section{Bibliography}

Adorno, , T. \& Horkheimer, M. (2002[1944]) The Dialectic of Enlightenment, Standford: Standford University Press

Allen, K (2011) Marx and the Alternative to Capitalism, London: Pluto

Anderson, P. (1977) Considerations on Western Marxism, London: Verso

Brenner, R. (2002) The boom and the bubble, the US in the world economy, New York: Verso

Calvert, P. (1970) Revolution, London: Macmillan

Cohen, G (1982) Karl Marx's Theory of History: A Defence, Oxford: Clarendon Press

Dahrendorf, R. (1959) Class and Class Conflict in Industrial Society, Stanford: Standford University Press

Eagleton, T (2011) Why Marx was Right, Yale: Yale University Press

Elias, N. (1984) 'The sociogensis of sociology’ in Sociologish Tijdschrift, May, no. 1.

Elias, N. (1971) Sociology of knowledge: new perspectives', Sociology vol.5.

Elias, N. (1983) The Court Society, Pantheon: New York

Elias, N. (1978) What is Sociology, London: Hutchinson

Elias, N. (1994) Reflections on a Life, Cambridge: Polity

Elias, N (1991) The Society of Individuals, Oxford, Blackwell

Elias (2012) 'Karl Marx as sociologist and political ideologist' in What is Sociology, Dublin: UCD Press, pp173-200 
Elias, N. \& Scotson, J (2008a) The Established and Outsiders, Dublin, UCD Press

Elias, N. (2008b) 'Processes of state formation ad nation-building in Collected Works, Norbert Elias Essays II: on civilising processes, state formation, and national identity, Dublin: UCD Press.

Harvey, D. (1999) The Limits to Capital, New York: Verso

Harvey, D. (2005) A Brief History of Neo-Liberalism,, Oxford: OUP

Lukacs, G. (1971) History and Class Consciousness: A Study in Marxist Dialectics, London: Merlin

Marx, K. \& Engels, F. (1848) The Communist Manifesto, London: Penguin

Marx, K. (1976 [1867]) Capital, London: Penguin

Marx, K. (1981[1865]) Capital Volume III, London: Pelican

Marx, K (1973[1958]) The Eighteenth Brumaire of Louis Napoleon, New York, International Publishers

Mennell, S. (1992) Norbert Elias: An Introduction, Dublin: UCD.

Meszaros, I. (1970), Marx's theory of Alienation, London: Merlin

Miliband, R (1991) 'State' in T. Bottomore (ed) A Dictionary of Marxist Thought, Oxford: Blackwell

Ollman, B. (1991) Dialectical Investigations, London: Routledge

Plekanov, G. (1940) The Materialist Conception of History, New York: International Publishers

Polyani, K. ([1944] 2001) The Great Transformation, Boston: Beacon Press.

Rosdolsky, R. (1989) The Making of Marx's Capital: London: Pluto

Sayer, D. (1985) 'The Critique of Politics and Political Economy: Capitalism, Communism and the State in Marx's writings of the mid-1840's', in The Sociological Review, Vol. 33: no. 2 pp221-253

Sayer, (1987) The Violence of Abstraction, Oxford: Blackwell.

Schaff, A (1973) 'Marxist Theory on Revolution and Violence', Journal of the History of Ideas, vol 34: No. 2

Sohn-Rethel, A. (1989) Intellectual and Manual Labour: A Critique of Epistemology, New Jersey: Humanities Press

Sweezy, P. (1946) The Theory of Capitalist Development, London: D Dobson

Thompson, E.P. (1968) The Making of the English working Class, London: Penguin Thompson, E.P. (1978) The Poverty of Theory, London: Merlin

Wacquant, L. (2003) 'Decivilizing and demonizing: the remaking of the black American ghetto' in S. Loyal and S. Quilley, The Sociology of Norbert Elias, Cambridge: CUP

Wright, E.O. (1985) Classes, London: Verso

Wright-Mills, C. 1973 ([1959]) The Sociological Imagination, London: Penguin 